Open Access

\title{
Targeting the 4-1BB costimulatory molecule through single chain antibodies promotes the human T-cell response
}

Salman Bagheri ${ }^{1,2,3}$, Elmira Safaie Qamsari ${ }^{1,2,3}$, Mehdi Yousefi ${ }^{2}$, Farhad Riazi-Rad ${ }^{1}$ and Zahra Sharifzadeh ${ }^{*}$

\author{
* Correspondence: zsharifzadeh@ \\ gmail.com \\ 'Department of Immunology, \\ Pasteur Institute of Iran, Tehran, Iran \\ Full list of author information is \\ available at the end of the article
}

\begin{abstract}
Background: Adoptive T-cell therapy (ACT) using autologous tumor-reactive T lymphocytes has considerable potential for cancer immunotherapy. In ACT, T cells are isolated from cancer patients and then stimulated and expanded in vitro by cytokines and costimulatory molecules. 4-1BB is an important costimulatory protein belonging to the TNF receptor superfamily. It is involved in T-cell survival, proliferation and activation. Agonistic anti-4-1BB monoclonal antibodies have been introduced as appropriate tools for ACT.

Methods: Here, various single-chain fragment variable (scFv) antibodies were used to activate $T$ cells isolated from peripheral blood via immune magnetic isolation. The $T$ cells were stimulated with IL-2 and anti-CD-3 mAb and then treated with agonistic anti-4-1BB scFvs. The results showed the remarkable effects of anti-41BB scFvs on the functional properties of $T$ cells, including their activation, proliferation and cytokine production. The flow cytometry analysis revealed a considerable increase in the expression of the T-cell activation marker CD69. Moreover, T-cell proliferation was evidenced in treated cells by CFSE labeling compared to the control groups.

Result: Anti-4-1BB scFvs significantly increased IFN- $\gamma$ and IL-2 mRNA and protein expression in T cells, but exhibited no stimulatory effect on IL-4 expression. These findings show that anti-4-1BB scFvs could evoke a Type I immune response.

Conclusions: Our results demonstrate that targeting the 4-1BB molecule using agonistic scFvs could be an effective strategy for T-cell stimulation as part of an ACT approach to cancer treatment.

Keywords: 4-1BB, Single-chain fragment antibody, T-cell therapy,

Immunomodulation, T cell responses
\end{abstract}

\section{Background}

4-1BB (CD137; TNFRSF9) is an inducible costimulatory molecule. It and its ligand were discovered in the 1980s in activated T cells and antigen-presenting cells (APCs) $[1,2]$. 4-1BB, a Type I membrane glycoprotein, is a member of the tumor necrosis factor receptor (TNFR) superfamily. It augments cellular immunity via signal transmission through protein-protein interactions that either extend survival or enhance

(c) The Author(s). 2020 Open Access This article is licensed under a Creative Commons Attribution 4.0 International License, which permits use, sharing, adaptation, distribution and reproduction in any medium or format, as long as you give appropriate credit to the original author(s) and the source, provide a link to the Creative Commons licence, and indicate if changes were made. The images or other third party material in this article are included in the article's Creative Commons licence, unless indicated otherwise in a credit line to the material. If material is not included in the article's Creative Commons licence and your intended use is not permitted by statutory regulation or exceeds the permitted use, you will need to obtain permission directly from the copyright holder. To view a copy of this licence, visit http://creativecommons.org/licenses/by/4.0/. 
costimulatory signals. The $4-1 \mathrm{BB}$ gene is localized on chromosome $1 \mathrm{p} 36$, close to other TNFR family members, including TNF-RII, OX40 and CD30. T-cell activation upregulates the expression of 4-1BB [3-5].

$4-1 \mathrm{BB}$ is induced within $24 \mathrm{~h}$ of activation. Signaling through the T-cell receptor (TCR) or CD3 can stimulate it on $\mathrm{T}$ cells $[4,6,7]$. Its expression has also been found on NKT cells, monocytes, macrophages, activated B cells, dendritic cells, eosinophils, neutrophils, epithelial and hepatoma cells, $\mathrm{CD} 11^{+}$dendritic cells and regulatory $\mathrm{T}$ cells $[8]$.

$4-1 \mathrm{BB}$ binds to its ligand (4-1BBL or CD137L), a transmembrane molecule of the TNF family that is expressed by APCs. 4-1BBL is induced after cell activation and can be regulated by LPS, Ig or CD40 signals $[4,6,7,9]$. In addition to T-cell costimulation through the $4-1 \mathrm{BB}$ receptor, $4-1 \mathrm{BBL}$ has the ability to enhance the activation and proliferation of APCs via reverse signaling $[7,10]$. Multiple studies have shown that 4-1BB acts as a costimulatory molecule for T-cell activation. The costimulatory signal provided by $4-1 \mathrm{BB}$ is involved in many $\mathrm{T}$-cell responses, including tumor immunity, allograft rejection and viral infection [11-13]. 4-1BB signals can costimulate $\mathrm{T}$ cells by activating the NF-кB, c-Jun and p38 downstream pathways independently of CD28 signals. It has been shown that 4-1BB signaling can activate the transcription of several genes with immune system involvement, such as those for T-cell expansion and those coding for interleukin-2 (IL-2) and IFN- $\gamma[7,14-16]$.

The biological effects of $4-1 \mathrm{BB}$ are varied and include the upregulation of antiapoptotic signals in $\mathrm{T}$ cells, the prevention of activation-induced cell death (AICD), the facilitation of differentiation into effector and memory cells, and the cell cycle progression and proliferation of $\mathrm{T}$ cells. In addition, it has been shown that 4-1BB signaling enhances TNF- $\alpha$ and IL-8 production by monocytes and can ameliorate AICD of neutrophils $[4,6,7]$.

Immunotherapy, chemotherapy and radiotherapy are used individually or in combination for the treatment of cancer, autoimmune diseases and other disorders. Adoptive cell therapy (ACT) is a treatment method in which $\mathrm{T}$-cell populations from patients are expanded in vitro in the presence of activating molecules, and then returned to the body. This approach relies on the in vivo development of sufficient numbers of natural host $\mathrm{T}$ cells with anti-tumor reactivity or host $\mathrm{T}$ cells genetically engineered with tumor-specific T-cell receptors (TCRs). T cells that are infused back into a patient after in vitro expansion can journey to the tumor and mediate cancer regression [17-19].

ACT has multiple advantages over other forms of cancer immunotherapy. It has been proven to be a safe and successful approach for establishing sustained T-cell responses. The infusion of small numbers of specific $\mathrm{T}$ cells could result in $\mathrm{T}$-cell expansion in vivo and give rise to long-term anti-tumor repression [17, 20]. A major hurdle to the development of ACT is the AICD of T cells and the loss of necessary molecules and specific costimulatory signaling pathways due to the in vitro culture conditions. This leads to reduced in vivo persistence after adoptive transfer [21]. It was found that CD8 tumor-infiltrating lymphocytes (TILs) upregulate costimulatory molecules of the TNF$R$ family, especially 4-1BB and, to a lesser extent, CD134/OX40, and lead to a loss of CD27 and CD28 expression during initial TCR stimulation [18, 22].

It has been shown that the agonistic monoclonal antibodies (mAbs) against 4-1BB could significantly inhibit AICD in T cells, increase their proliferation and survival, and 
enhance their cytotoxicity. Moreover, they increased the yield of CD8 T cells and enhanced effector memory properties [18, 23].

Costimulation through the 4-1BB pathway protects human melanoma tumorinfiltrating lymphocytes from AICD and significantly enhances their anti-tumor effects [23]. It has also been proven that $4-1 \mathrm{BB}^{+}$TILs mediate higher anti-tumor effects in vivo, compared with 4-1BB- TILs, which reveals the important role of 4-1BB in antitumor immunity [24]. The application of anti-4-1BB mAbs in clinical trials alone or in combination with cytotoxic T lymphocytes (CTL) yielded promising clinical outcomes. Their effective synergism resulted in complete eradication and growth control of melanoma tumors [25]. Various therapeutic strategies have been investigated for the stimulation of $4-1 \mathrm{BB}$, and their promise in cancer immunotherapy has been demonstrated $[26,27]$.

We previously used phage display technology to isolate four anti-4-1BB single-chain fragment variable antibodies (scFvs), called PI.12, PI.42, PII.16 and PII.29 [28]. These antibody fragments specifically bind to $4-1 \mathrm{BB}$, activate $\mathrm{T}$ cells and increase IL-2 production. In an attempt to generate $\mathrm{T}$ cells with improved biological activity, we treated human $\mathrm{T}$ cells with anti-4-1BB scFvs and studied their activation status, proliferation rate and cytokine production. The results of this research indicate that these scFvs are promising tools to produce $\mathrm{T}$ cells suitable for adoptive cell therapy.

\section{Materials and methods} Isolation of $\mathrm{T}$ cells from whole blood

This study was approved by the Ethics Committee in the Pasteur Institute of Iran. After receiving informed consent, fresh heparinized peripheral blood samples were collected from five healthy adult volunteer donors. Using Ficoll-Paque (Sigma) and density gradient centrifugation, peripheral blood mononuclear cells (PBMCs) were isolated from whole blood. Negative selection (depletion of unwanted cells) was used to purify human $\mathrm{CD}^{+} \mathrm{T}$ cells from PBMC using magnetic affinity cell sorting (MACS) and the Naive Pan T-Cell Isolation Kit (Miltenyi Biotech). The PBMCs were washed twice with MACS buffer reagent (Miltenyi Biotech), centrifuged at $300 \times \mathrm{g}$ for $10 \mathrm{~min}$ at $20^{\circ} \mathrm{C}$ and the supernatant was completely removed. The cell pellet was resuspended in $40 \mu \mathrm{l}$ of isolation buffer per $10^{7}$ total cells. Then, to deplete all the non-target cells, a cocktail of biotin-conjugated mAbs against non-T-cell markers was used for their labelling. After incubation, $30 \mathrm{ml}$ buffer and $20 \mathrm{ml}$ Naive Pan T-Cell Micro Bead Cocktail were added (for $10^{7}$ total cells). Following an additional incubation on ice for $10 \mathrm{~min}$, all the magnetically-tagged unwanted cells were removed by retaining them on the MACS column of a MACS separator. All non-labeled $\mathrm{CD}^{+} \mathrm{T}$ cells were washed out from the column and collected in the tube (Fig. 1a) [29, 30].

\section{T-cell purity assessment using flow cytometry}

Isolated T-cell purity was analyzed using flow cytometry with anti-human CD3 monoclonal antibody with fluorescein isothiocyanate (FITC; eBioscience). Briefly, T cells were washed with washing buffer (PBS $0.15 \mathrm{M}, 0.5 \% \mathrm{BSA}, 0.1 \% \mathrm{NaN}_{3}$ ), resuspended in buffer, and then labeled with anti-CD3 FITC mAb for $40 \mathrm{~min}$ at $4{ }^{\circ} \mathrm{C}$ in a dark place. The cells were then washed again with the washing buffer. The percentage of $\mathrm{CD}^{+}$ 


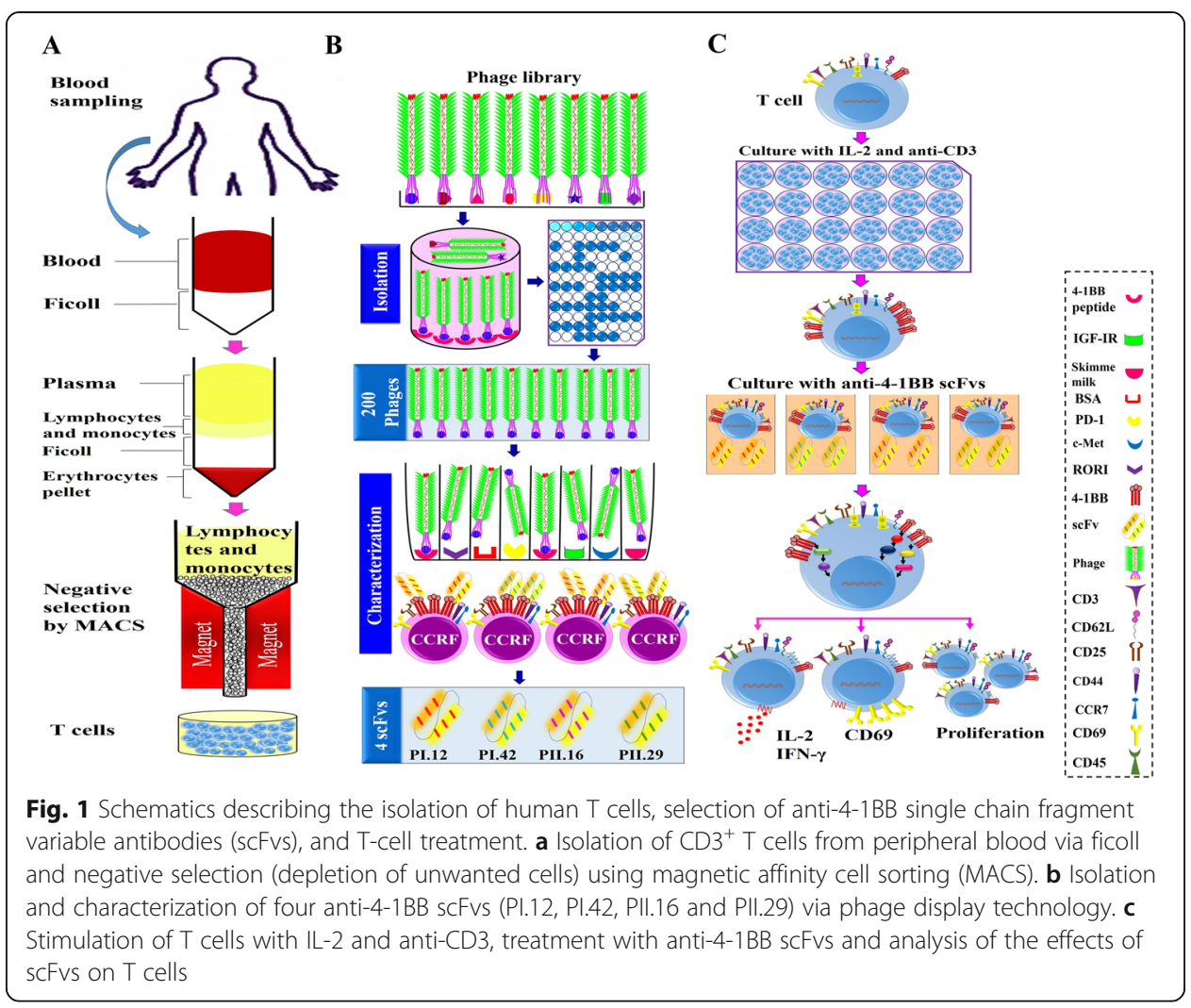

cells was determined using a Partec PASIII flow cytometer (Partec). A minimum of 100,000 events was acquired, and the data analysis was performed using FlowJo software (v.7.2.5; Tree Star).

\section{T-cell stimulation methods}

Comparison of in vitro $\mathrm{T}$-cell stimulation methods was initially performed to obtain optimized stimulation conditions. For this, $10^{6} \mathrm{~T}$-cells in RPMI-1640 containing 15\% heat-inactivated fetal bovine serum (FBS; Gibco) were seeded into 24-well plates. Then, $\mathrm{T}$ cells were treated for $24 \mathrm{~h}$ at $37^{\circ} \mathrm{C}$ in $5 \% \mathrm{CO}_{2}$ with different concentrations of IL-2 (soluble form, R\&D Systems), anti-CD3 (soluble form, Mabtech) or PHA $(5 \mu \mathrm{g} / \mathrm{ml}$ ) as a positive control (Table 1). Cell count and viability were determined using Trypan blue staining [31, 32].

\section{T-lymphocyte treatment with anti-4-1BB scFvs}

To evaluate the impact of anti-4-1BB scFvs on T-cell activation, proliferation and cytokine production, primary $\mathrm{T}$ cells were treated with the antibody fragments. Anti-4-1BB scFvs, including PI.12, PI.42, PII.16 and PII.29, were selected and produced as previously described (Fig. 1b). Freshly purified T cells were maintained in RPMI 1640 medium containing $20 \% \mathrm{FBS}, 100 \mu \mathrm{g} / \mathrm{ml}$ streptomycin, and $100 \mathrm{U} / \mathrm{ml}$ penicillin. After that, cells were grown for $36 \mathrm{~h}$ in the presence of IL-2 and anti-CD3 antibody at $37{ }^{\circ} \mathrm{C}$ in a humidified $\mathrm{CO}_{2}$ incubator. For cell treatment, $500 \times 10^{3}$ purified T-cells were 
Table 1 Summary of the T cell stimulation methods used

\begin{tabular}{lll}
\hline NO & IL-2(IU/ml) & Anti-CD3 (ng/ml) \\
\hline 1 & $100 \mathrm{IU} / \mathrm{ml}$ & - \\
2 & $200 \mathrm{IU} / \mathrm{ml}$ & - \\
3 & $300 \mathrm{IU} / \mathrm{ml}$ & - \\
4 & - & $100 \mathrm{ng} / \mathrm{ml}$ \\
5 & - & $200 \mathrm{ng} / \mathrm{ml}$ \\
6 & - & $300 \mathrm{ng} / \mathrm{ml}$ \\
7 & $100 \mathrm{IU} / \mathrm{ml}$ & $100 \mathrm{ng} / \mathrm{ml}$ \\
8 & $200 \mathrm{IU} / \mathrm{ml}$ & $100 \mathrm{ng} / \mathrm{ml}$ \\
9 & $300 \mathrm{IU} / \mathrm{ml}$ & $100 \mathrm{ng} / \mathrm{ml}$ \\
10 & $100 \mathrm{IU} / \mathrm{ml}$ & $200 \mathrm{ng} / \mathrm{ml}$ \\
11 & $200 \mathrm{IU} / \mathrm{ml}$ & $200 \mathrm{ng} / \mathrm{ml}$ \\
12 & $300 \mathrm{IU} / \mathrm{ml}$ & $200 \mathrm{ng} / \mathrm{ml}$ \\
13 & $100 \mathrm{IU} / \mathrm{ml}$ & $300 \mathrm{ng} / \mathrm{ml}$ \\
14 & $200 \mathrm{IU} / \mathrm{ml}$ & $300 \mathrm{ng} / \mathrm{ml}$ \\
15 & $300 \mathrm{IU} / \mathrm{ml}$ & $300 \mathrm{ng} / \mathrm{ml}$ \\
\hline
\end{tabular}

seeded into 24- and 48-well plates and treated with $10 \mu \mathrm{g} / \mathrm{ml}$ different scFvs for $72 \mathrm{~h}$ (Fig. 1c) [28].

\section{Flow cytometry assessment of T-cell activation marker}

To investigate the effect of PI.12, PI.42, PII.16 and PII.29 scFvs on T-cell activation, CD69 upregulation was measured via flow cytometry. In brief, after a 24-h treatment with anti-4-1BB and an unrelated scFv (anti-c-Met scFv named ES1) [33], one million cells were washed with washing buffer, labeled with PE-conjugated anti-CD69 antibody $\mathrm{mAb}$ (eBioscience), and analyzed using flow cytometry. Untreated $\mathrm{T}$ cells were used as a negative control. A minimum of 100,000 events were acquired. All data analysis was performed using the FlowJo software (v.7.2.5; Tree Star) [28].

\section{Proliferation assay}

To assess the impact of anti-4-1BB scFvs on the proliferation of $\mathrm{T}$ cells, cell division analysis was performed by examining 5- and 6-carboxyfluorescein diacetate succinimidyl ester (CFSE) (eBioscience) dilution in labeled cell populations. Briefly, $\mathrm{T}$ cells were washed and stained with CFSE reagent at a concentration of $5 \mu \mathrm{M}$ for $10 \mathrm{~min}$ at $37^{\circ} \mathrm{C}$. Then the cells were washed, recounted and treated with scFvs for $72 \mathrm{~h}$ at $37^{\circ} \mathrm{C}$. After that, flow cytometry was used to detect CFSE-labeled cells [34].

\section{Real-time PCR}

The mRNA levels of IL-2, IL-4 and IFN- $\gamma$ were examined using real-time PCR. Briefly, total RNA extraction was performed from $T$ cells treated with scFvs with an RNeasy Mini Kit (Qiagen). After that, transcription into cDNA was performed using $1 \mathrm{mg}$ total RNA and a cDNA synthesis kit (Roche). The expression levels of IL-2, IL-4 and IFN- $\gamma$ mRNA were quantified with a Two-Step Quanti Test SYBR Green RT-PCR kit (Takara), using a Corbett Rotor-Gene 6000 thermal cycler (Corbett Life Science). 
Primers for IL-2, IL-4 and IFN- $\gamma$ were designed using Primer-Blast software (NCBI). Hypoxanthine-guanine phosphoribosyl transferase (HPRT) was used as the housekeeping gene (Table 2). Differences in cytokine mRNA expression levels were determined using the $2-{ }^{\Delta \Delta \mathrm{Ct}}$ method.

\section{Cytokine analysis via ELISA}

The effect of anti-4-1BB scFvs on IL-2, IL-4 and IFN- $\gamma$ secretion was evaluated in treated T-cells using ELISA. For this, T cells were seeded at $10^{5}$ cells/well in 96 -well cell culture microplates. After $48-72 \mathrm{~h}$ incubation with anti-4-1BB scFvs, cytokine levels were measured in cell culture supernatants using ELISA with a cytokine detection kit for IL-2 and IFN- $\gamma$ from eBioscience and for IL-4 from R\&D Systems according to the manufacturer's instructions. To create standard curves and regression analysis of mean absorbance, standard cytokine solutions were run in parallel. The optical density at $450 \mathrm{~nm}$ was measured for each well using a microtiter plate reader (BP-800; Bioship) and the cytokine concentration was obtained from standard curves of recombinant human IL-2, IL-4 and IFN- $\gamma$ [35].

\section{Statistical analysis}

The statistical difference between two groups was compared with Student's t-test. Intergroup comparisons were made using the Kruskal-Wallis non-parametric ANOVA test. All data were analyzed using Graph Pad Prism version 6.01 software (Graph Pad). Results are reported as the means \pm standard deviation (SD). $p<0.05$ was considered to be statistically significant.

\section{Results}

\section{T-cell isolation and stimulation optimization}

Human primary $\mathrm{T}$ cells were isolated from $\mathrm{PBMC}$, and their purity was determined using flow cytometry analysis to be about 90\% (Fig. 2). Various IL-2 and anti-CD3 antibody concentrations were used to stimulate $\mathrm{T}$ cells. It was found that stimulation of $\mathrm{T}$ cells with $300 \mathrm{IU} / \mathrm{ml} \mathrm{IL-2}$ in combination with $200 \mathrm{ng} / \mathrm{ml}$ anti-CD3 antibody resulted in the best cell viability (95\%) and proliferation. T-cell viability was about $60 \%$ in the absence of stimulatory molecules.

\section{Anti-4-1BB scFvs induces CD69 expression on T cells}

The activation state of $\mathrm{T}$ cells was evaluated using flow cytometry analysis of CD69 expression. The expression of CD69 significantly increased on T cells treated with anti-4-1BB compared to that on untreated cells and cells treated with control

Table 2 Primer sequences for real-time PCR

\begin{tabular}{lll}
\hline Gene & Primer sequence & \\
\cline { 2 - 3 } & Forward & Reverse \\
\hline IL-2 & ATGTACACCATGCAACTCCTGTCT & GTCAGTGTTGAGATGATGCTTTGA \\
$\mathrm{IL}-4$ & GCCTCACAGAGCAGAAGAACAC & GTGGCTTCCTTCACAGGACAG \\
$\mathrm{IFN}-\boldsymbol{\gamma}$ & GGGTTCTCTTGGCTGTTACT & GAGTTCCATTATCCGCTACATCT \\
HPRT & AATTATGGACAGGACTGAACGTCTTGCT & TCCAGCAGGTCAGCAAAGAATTATAGC \\
\hline
\end{tabular}



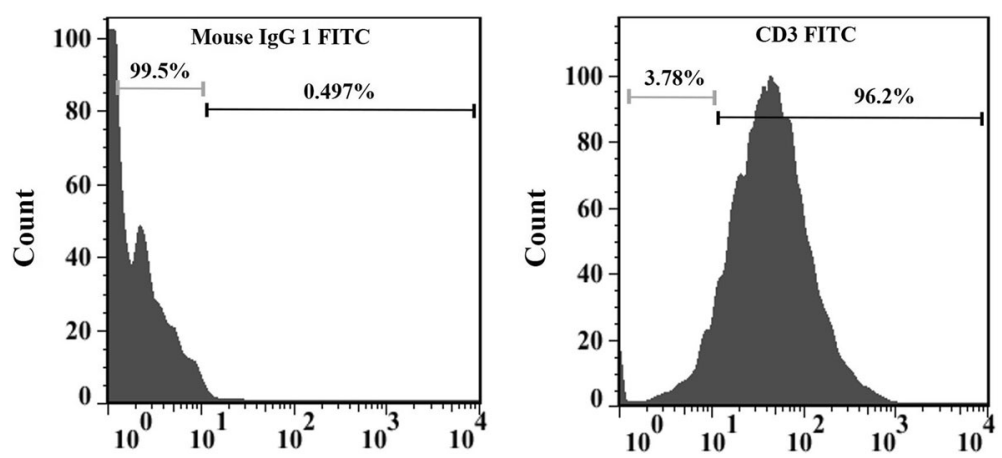

Fig. 2 The purity of $\mathrm{CD}^{+}$primary T cells isolated from PBMCs using MACS. The isolated cells were stained with anti-CD3 conjugated to FITC and isotype control antibody and analyzed via flow cytometry. The histograms show the isotype-controlled cells (left) and anti-CD3 stained T cells (right) of the enriched fraction. Results are representative of three independent experiments

scFv (ES1; $p<0.05$; Fig. 3). The average expression increased from $1.5 \pm 0.2 \%$ on non-treated to $36.2 \pm 2.0,15.8 \pm 1.1,30.3 \pm 2.1$ and $43.5 \pm 2.0 \%$ for cells treated with PI.12, PI.42, PII.16 and PII.29 scFvs, respectively.

\section{Anti 4-1BB scFv enhances T-cell division and proliferation}

CFSE labeling was used to determine whether anti-4-1BB scFvs increase the ability of $\mathrm{T}$ cells to divide. T cells stimulated with IL-2 and anti-CD3 were stained with CFSE, incubated with or without scFvs for two days, and analyzed for the number of divisions undergone. All scFvs examined showed clear evidence of cell division compared to the unrelated scFv (Fig. 4). Treatment with PI.12, PI42, PII.16 and PII.29 anti-4-1BB scFvs

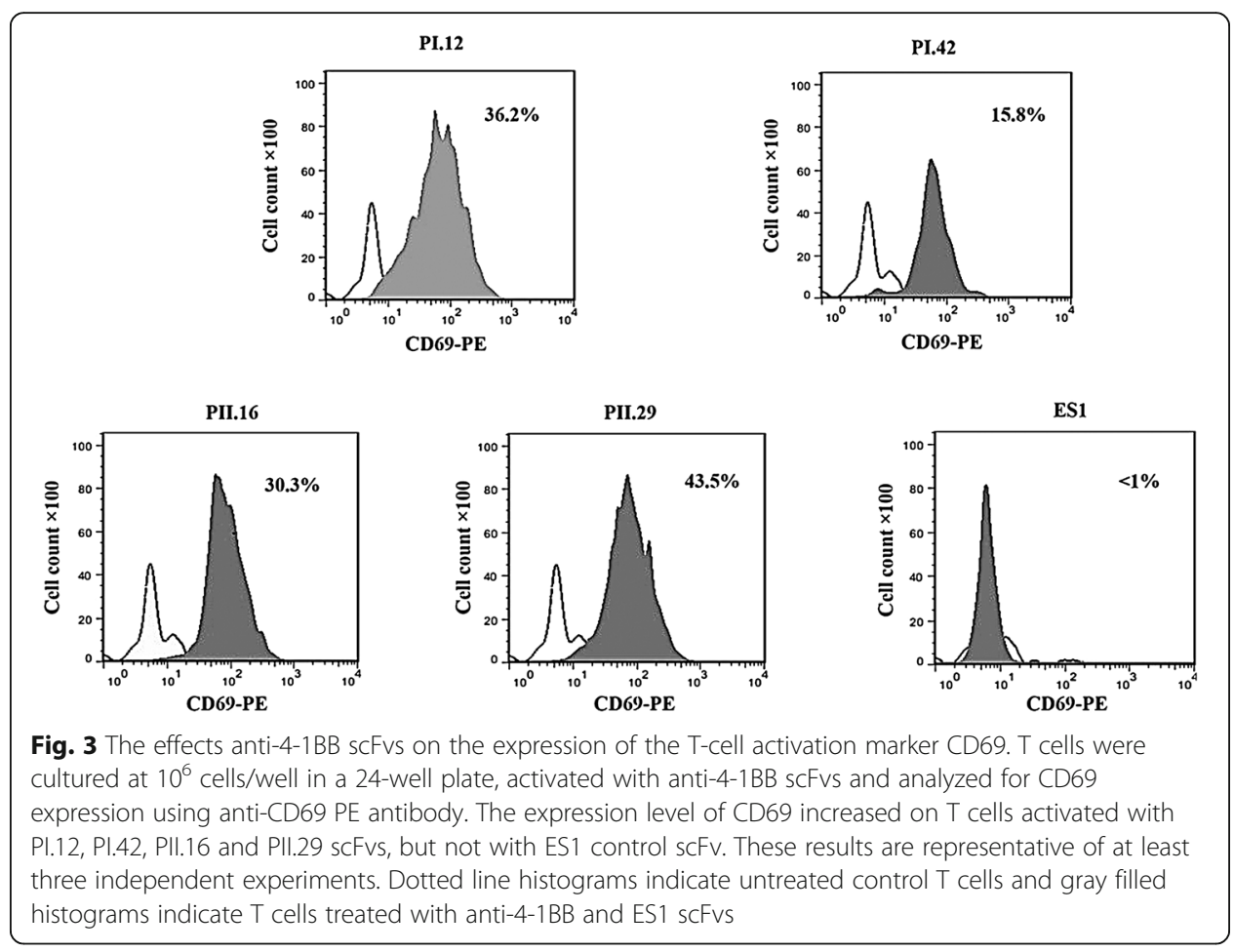




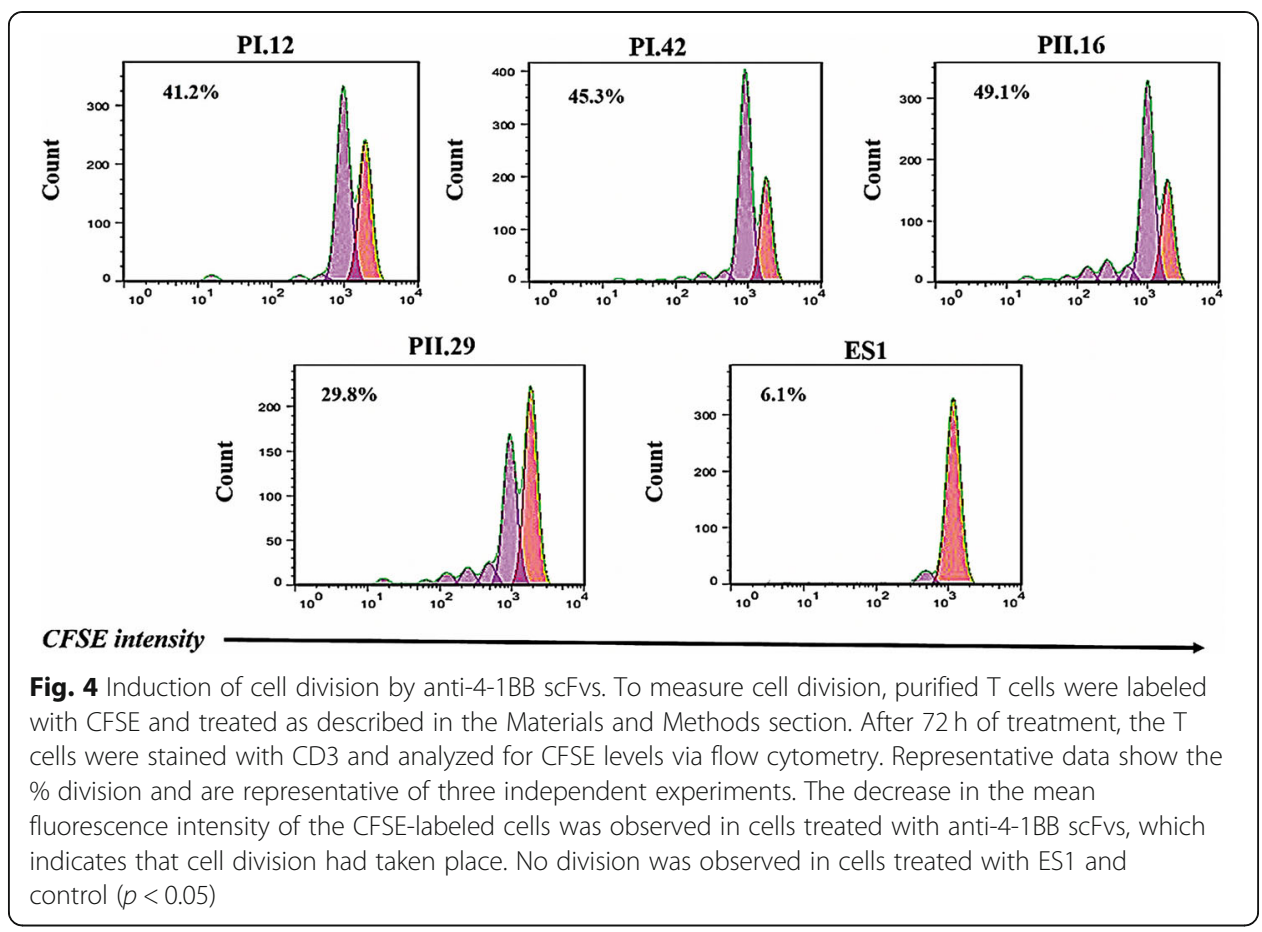

increased the cell division $(p<0.05)$ to $41.2,49.9,45.3$ and $29.8 \%$, respectively. These results show that anti-4-1BB scFvs could provide a costimulatory signal to induce cell division in $\mathrm{T}$ cells.

\section{The mRNA expression of IL-2and IFN- $\gamma$ increases in treated T cells}

The effect of anti-4-1BB scFvs on the expressions of IL-2, IL-4 and IFN- $\gamma$ mRNA was examined via real-time PCR using specific primers. A significant increase in the mRNA expression levels of IFN- $\gamma$ and IL-2 was observed after $48 \mathrm{~h}$ treatment with scFvs (Fig. 5). PI.12, PII.16 and PII.29 anti-4-1BB scFvs respectively increased the IFN- $\gamma$ mRNA expression from $1.00 \pm 0.15$ in the control cells to $42.7 \pm 2.1(p<0.0001), 34.4 \pm$ $1.48(p<0.0001)$ and $16.02 \pm 1.15(p=0.0004)$ in the treated cells. Moreover, PI.42 $(10.4 \pm 1.1)$ and control scFv $(7.9 \pm 1.08)$ could not significantly alter the expression of IFN- $\gamma$ mRNA in the treated cells (Fig. 5a).

Furthermore, IL-2 mRNA expression increased from $1.2 \pm 0.2$ to $7.4 \pm 0.3(p=0.001)$, $6.2 \pm 0.2(p=0.001)$ and $8.15 \pm 0.25(p=0.0004)$ in T cells treated with PI.12, PII.16 and PII.29 scFvs, respectively, and no significant difference of IL-2 expression was observed in PI.42-treated $(3.1 \pm 0.1)$ and control scFv $(2.2 \pm 0.15)$ cells (Fig. 5a). Anti-4-1BB scFvs had no significant effect on the mRNA level of IL-4 in the T cells (Fig. 5a).

\section{Anti-4-1BB scFvs induced IL-2 and IFN- - production in T cells}

The levels of IL-2, IL-4 and IFN- $\gamma$ secreted by treated T cells were determined using ELISA. IFN $-\gamma$ production increased from $211.8 \pm 14.12 \mathrm{pg} / \mathrm{ml}$ in the control group to $6210 \pm 112(p=0.0001), 5050( \pm 103(p=0.0001)$ and $2610 \pm 101(p=0.004) \mathrm{pg} / \mathrm{ml}$ in the PI.12-, PII.16- and PII.29-treated cells, respectively. PI.42 increased IFN- $\gamma$ production $(1425 \pm 75)$ but the difference was not significant. Also, ES1 was not able to induce 


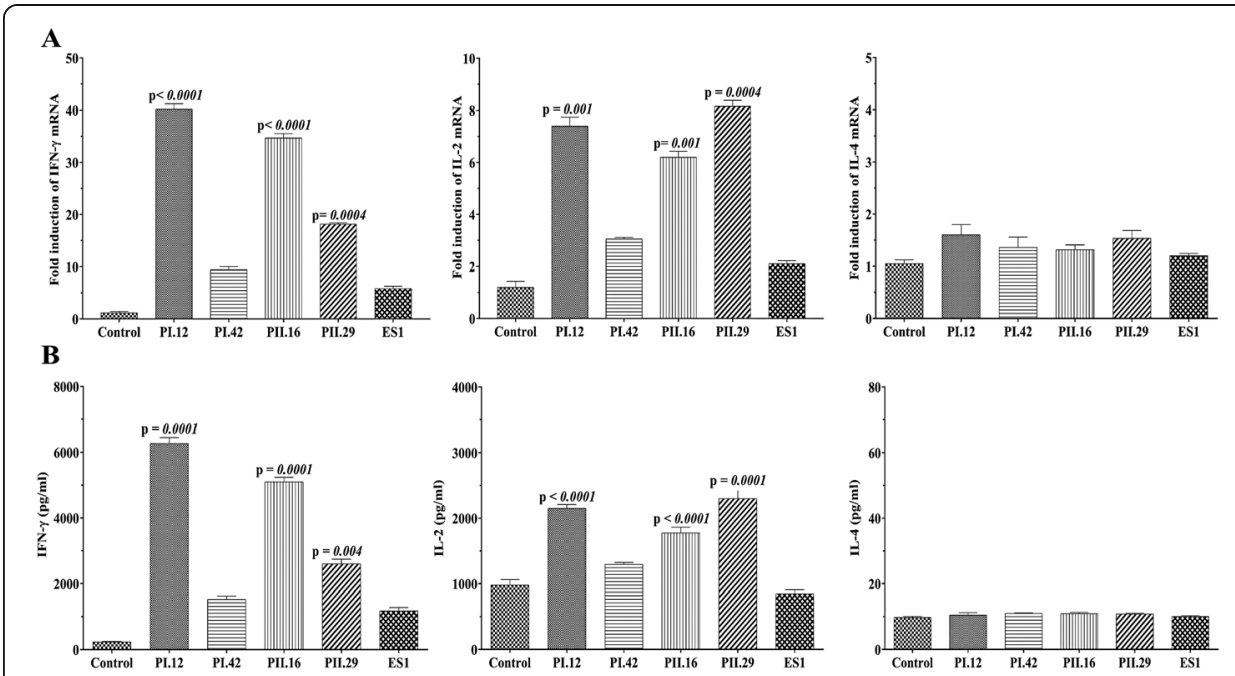

Fig. 5 Cytokine mRNA expression and enhanced IFN- $\gamma$ and IL-2 production in T cells treated with anti-41BB scFvs. a Following $72 \mathrm{~h}$ of treatment with anti-4-1BB scFvs, cells were collected and analyzed for IFN- $\gamma$, IL-2 and IL-4 mRNA expression levels using real-time PCR, with the amplification normalized against HPRT. Results from quantitative real-time PCR demonstrate that mRNA for IFN- $\gamma$ and IL-2 was significantly increased in T cells treated with PI.12, PII.16 and PII.29 scFvs.PI.42 and that ES1 scFvs could not induce IFN- $\gamma$ and IL-2 production in T cells. No IL-4 mRNA expression was observed in the treated cells. NS: no significant difference. ${ }^{*} p<0.05$. Data represent the mean of three experiments \pm SD. $\mathbf{b}$ Cytokine secretion by T-cells treated with anti-4-1BB scFvs was determined using ELISA. IFN- $\gamma$ and IL-2 increased significantly following treatment of T cells with PI.12, PII.16 and PII.29 scFvs $(p<0.05)$, while the increase in IL-4 production was not significant. The results shown are means \pm SD amounts of cytokine secreted by treated T cells (in pg/ $\mathrm{ml})$. Each experiment was repeated a minimum of three times

IFN- $\gamma$ production in treated cells $(1180 \pm 70$; Fig. $5 \mathrm{~b})$. In addition, the treatment of $\mathrm{T}$ cells with anti-4-1BB scFvs led to a significant increase in the secretion of IL-2 by T cells compared with the untreated control group (Fig. 5b). The results showed that anti-4-1BB scFvs had no effects on the production of IL-4 by T cells (Fig. $5 \mathrm{~b}$ ).

\section{Discussion}

Cancer treatment strategies include chemotherapy, radiotherapy and immunotherapy, which can be applied individually or in combination. ACT has emerged as a realistic technique for cancer treatment $[36,37]$.

However, the success of adoptive T-cell therapy has been limited to certain tumor types, in part due to tumor-induced T-cell inactivation [18, 38, 39]. Several strategies have been exploited to improve the proliferative potential and therapeutic efficacy of $\mathrm{T}$ lymphocytes for adoptive cell therapy. Agents that enhance the anti-tumor functions of immune cells are a promising novel group of immunotherapeutics. mAbs acting as checkpoint inhibitors or co-receptor agonists have been used to enhance the survival and activation of the $\mathrm{T}$ cells $[18,23]$.

In this study, we used the agonistic anti-4-1BB scFvs PI.12, PI.42, PII.16 and PII. 29, which were produced and selected as previously described. T cells were isolated from the human peripheral blood using the MACS technique and stimulated with IL-2, antiCD3 mAb and anti-4-1BB scFvs. The effect of anti-4-1BB scFvs treatment was 
investigated via flow cytometry analysis of CD69 expression, determination of IL-2, IL4 and IFN- $\gamma$ production, and T-cell proliferation assay.

It was shown that $\mathrm{T}$-cell treatment with anti-4-1BB scFvs enhanced the expression of T cell activation marker (CD69) on the surface of T cells (Fig. 3) and induced IL-2 and IFN- $\gamma$ mRNA expression and protein production, but did not increase IL-4 production (Fig. 5a and b). It also obviously increased the proliferation capability of T cells (Fig. 4). The results of IL-2 production and CD69 expression in T cells concur with the results our previous study in which IL-2 and CD69 expression were evaluated in treated CCRF-CEM cells.

In a similar study by Hernandez-Chacon et al., the effect of anti-4-1BB mAb on the proliferation of TILs was investigated [23]. 4-1BB signaling mediated by anti-4-1BB $\mathrm{mAb}$ could facilitate the continued proliferation of TIL after TCR-CD3 stimulation and prevent AICD, probably by regulating BCL- 2 family proteins, thereby serving as an alternative costimulatory pathway in TIL used for ACT. Wen et al. [34] reported that 41BBL could stimulate both CD4 and CD8 T cells and induce T-cell expansion. Cooper et al. showed that 4-1BB enhances the proliferation and survival of cytotoxic $\mathrm{T}$ cells in vivo [40]. Shuford et al. exmined in vivo effects of anti-4-1BB mAbs on antigeninduced T-cell activation and showed that 4-1BB triggering preferentially enhances CD8 $\mathrm{T}$ cell expansion and contributes to the induction of cytotoxic $\mathrm{T}$-cell responses [41]. Daniel-Meshulam et al. found that T-cell stimulation by 4-1BB can increase IFN$\gamma$ production and enhance anti-tumor activity [31]. Miller et al. showed that the 4-1BBspecific monoclonal antibody triggers tumor immune responses through IFN- $\gamma$ induction.

Previous studies also demonstrated that targeting 4-1BB could improve T-cell responses and mediate anti-tumor activity. The results of Hernandez-Chacon et al. indicate that the provision of 4-1BB costimulation through monoclonal antibodies could improve the survival of TIL during melanoma ACT and boost anti-tumor effector functions [23]. In another study, it was demonstrated that the addition of an agonistic anti$4-1 \mathrm{BB}$ antibody to the Rapid Expansion Protocol (REP) could enhance the frequency and total yield of tumor-reactive CTLs and increase their anti-tumor activity and survival capability when re-cultured with or without cytokines [42].

It is well documented that the cross-linking of 4-1BB via ligand-induced trimerization is essential for inducing strong downstream signaling [43]. Therefore, the previous studies used mAbs or [44] multivalent scFvs to [45] trigger the 4-1BB signaling pathway. By contrast, the monovalent 4-1BB specific scFvs used in this study could induce the 4-1BB signaling pathway alone. Moreover, it has been reported that some monovalent scFvs against other TNFR superfamily members could induce receptor crosslinking and initiate cell signaling [46-48]. This might be because of the different binding sites of the scFvs from those of 4-1BBL on 4-1BB that lead to induction of different conformations in the 4-1BB intracellular domain and subsequently different signaling outcomes. Like other TNFR families, each 4-1BB is composed of four cysteine-rich domains (CRDs), CRD1 to CRD4. It exists on the T-cell surface in both monomeric and dimeric forms. It has been reported that 4-1BBL and utomilumab, an agonistic anti-4$1 \mathrm{BB} \mathrm{mAb}$, have completely different binding areas on $4-1 \mathrm{BB}$. The binding region of 4$1 B B L$ is located on CRD2 and CRD3, while utomilumab binds to dimeric 4-1BB via CRD3 and CRD4 with partial contacts to CRD2 [49, 50]. Moreover, cross-linking of 4- 
$1 \mathrm{BB}$ by utomilumab is relegated by the ratio of mono- to di-4-1BBs which is different from trimeric 4-1BBL [51].

These scFvs have been isolated from a fully human phage display library, so they will not elicit immune responses in the patients. In comparison to the previously studied full-length anti-4-1BB antibodies, these novel single-chain antibodies have many advantages, including smaller size, lower cost and ease of production, which make them suitable for targeting 4-1BB in ACT and for use in a variety of studies.

\section{Conclusions}

The novel human anti-4-1BB scFvs improved various T-cell functional activities, including enhanced cell division, and increased IL-2 and IFN- $\gamma$ production. Since the scFvs could increase Type I (IL-2 and IFN- $\gamma$ ), but not Type II cytokines (IL-4), it can be concluded that they may induce T-cell-mediated Type I immune responses.

In recent years, substantial progress has been achieved in elucidating the therapeutic potential of anti-4-1BB antibodies alone or in conjunction with other FDA-approved immunomodulatory substances. Current clinical trials on 4-1BB agonists proved the importance of $4-1 \mathrm{BB}$ as an emerging therapeutic target. Although our results provide evidence for the immunomodulation advantages of anti-41BB scFvs, further studies are needed to evaluate their in vivo T-cell activation and their anti-tumor effects.

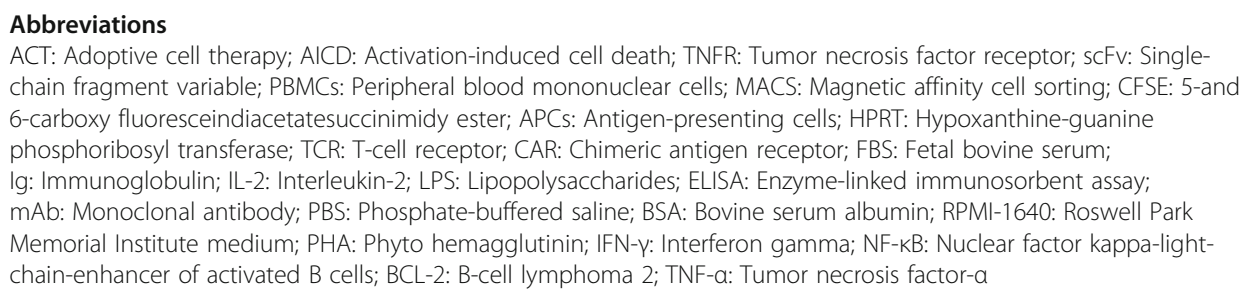

Ethics approval and consent to participate

The study was approved by the Ethics Committee of Pasteur Institute of Iran (Approved NO IR.PII.REC.1394.4, 2015/07/ 28) and was carried out according to the principles of the Declaration of Helsinki (2000).

Consent for publication

Not applicable.

Competing interests

The authors declare that they have no competing interests.

\section{Author details}

${ }^{1}$ Department of Immunology, Pasteur Institute of Iran, Tehran, Iran. ${ }^{2}$ Department of Immunology, School of Medicine, Tabriz University of Medical Sciences, Tabriz, Iran. ${ }^{3}$ Immunology Research Center, Tabriz University of Medical Sciences, Tabriz, Iran. 
Received: 12 July 2019 Accepted: 27 March 2020

Published online: 22 April 2020

\section{References}

1. Vinay DS, Cha K, Kwon BS. Dual immunoregulatory pathways of 4-1BB signaling. J Mol Med (Berl). 2006;84:726-36.

2. Kwon BS, Weissman SM. cDNA sequences of two inducible T-cell genes. Proc Natl Acad Sci U S A. 1989;86:1963-7.

3. Weiss A, Littman DR. Signal transduction by lymphocyte antigen receptors. Cell. 1994;76:263-74.

4. Vinay DS, Kwon BS. Role of 4-1BB in immune responses. Semin Immunol. 1998;10:481-9.

5. Kim JO, Kim HW, Baek KM, Kang CY. NF-KB and AP-1 regulate activation-dependent CD137 (4-1BB) expression in T cells. FEBS Lett. 2003;541:163-70.

6. Croft M. Co-stimulatory members of the TNFR family: keys to effective T-cell immunity. Nat Rev Immunol. 2003;3:609-20.

7. Watts TH. TNF/TNFR family members in costimulation of T cell responses. Annu Rev Immunol. 2005;23:23-68.

8. Vinay DS, Kwon BS. 4-1BB signaling beyond T cells. Cell Mol Immunol. 2011;8:281-4.

9. Barsoum AL, Schwarzenberger PO. Oncofetal antigen/immature laminin receptor protein in pregnancy and cancer. Cell Mol Biol Lett. 2014;19:393-406.

10. Drenkard D, Becke FM, Langstein J, Spruss T, Kunz-Schughart LA, Tan TE, et al. CD137 is expressed on blood vessel walls at sites of inflammation and enhances monocyte migratory activity. FASEB J. 2007;21:456-63.

11. Mittler RS, Foell J, McCausland M, Strahotin S, Niu L, Bapat A, et al. Anti-CD137 antibodies in the treatment of autoimmune disease and cancer. Immunol Res. 2004;29:197-208.

12. Mittler RS, Bailey TS, Klussman K, Trailsmith MD, Hoffmann MK. Anti-4-1BB monoclonal antibodies abrogate T celldependent humoral immune responses in vivo through the induction of helper T cell anergy. J Exp Med. 1999;190: $1535-40$.

13. Miller RE, Jones J, Le T, Whitmore J, Boiani N, Gliniak B, et al. 4-1BB-specific monoclonal antibody promotes the generation of tumor-specific immune responses by direct activation of CD8 T cells in a CD40-dependent manner. J Immunol. 2002;169:1792-800.

14. Saoulli K, Lee SY, Cannons JL, Yeh WC, Santana A, Goldstein MD, et al. CD28-independent, TRAF2-dependent costimulation of resting T cells by 4-1BB ligand. J Exp Med. 1998;187:1849-62.

15. Cannons JL, Hoeflich KP, Woodgett JR, Watts TH. Role of the stress kinase pathway in signaling via the $T$ cell costimulatory receptor 4-1BB. J Immunol. 1999;163:2990-8.

16. Galoczova M, Coates P, Vojtesek B. STAT3, stem cells, cancer stem cells and p63. Cell Mol Biol Lett. 2018;23:12.

17. Pilon-Thomas S, Kuhn L, Ellwanger S, Janssen W, Royster E, Marzban S, et al. Brief communication: efficacy of adoptive cell transfer of tumor infiltrating lymphocytes after lymphopenia induction for metastatic melanoma. J Immunother. 2012:35:615-20.

18. Restifo NP, Dudley ME, Rosenberg SA. Adoptive immunotherapy for cancer: harnessing the T cell response. Nat Rev Immunol. 2012;12:269-81.

19. Rosenberg SA, Restifo NP. Adoptive cell transfer as personalized immunotherapy for human cancer. Science. 2015;348: 62-8.

20. Radvanyi LG, Bernatchez C, Zhang M, Fox PS, Miller P, Chacon J, et al. Specific lymphocyte subsets predict response to adoptive cell therapy using expanded autologous tumor-infiltrating lymphocytes in metastatic melanoma patients. Clin Cancer Res. 2012;18:6758-70.

21. Paulos CM, Wrzesinski C, Kaiser A, Hinrichs CS, Chieppa M, Cassard L, et al. Microbial translocation augments the function of adoptively transferred self/tumor-specific CD8+ T cells via TLR4 signaling. J Clin Invest. 2007;117:2197-204.

22. Chacon JA, Wu RC, Sukhumalchandra P, Molldrem JJ, Sarnaik A, Pilon-Thomas S, et al. Co-stimulation through 4-1BB/ CD137 improves the expansion and function of CD8+ melanoma tumor-infiltrating lymphocytes for adoptive T-cell therapy. PLoS One. 2013;8:e60031.

23. Hernandez-Chacon JA, Li Y, Wu RC, Bernatchez C, Wang Y, Weber J, et al. Co-stimulation through the CD137/4-1BB pathway protects human melanoma tumor-infiltrating lymphocytes from activation-induced cell death and enhances anti-tumor effector function. J Immunother. 2011;34:236-50.

24. Ye Q, Song DG, Poussin M, Yamamoto T, Best A, Li C, et al. CD137 accurately identifies and enriches for naturally occurring tumor-reactive T cells in tumor. Clin Cancer Res. 2014;20:44-55.

25. Weigelin B, Bolaños E, Teijeira A, Martinez-Forero I, Labiano S, Azpilikueta A, et al. Focusing and sustaining the antitumor CTL effector killer response by agonist anti-CD137 mAb. Proc Natl Acad Sci U S A. 2015;112:7551-6.

26. Gauttier V, Judor JP, Le Guen V, Cany J, Ferry N, Conchon S. Agonistic anti-CD137 antibody treatment leads to antitumor response in mice with liver cancer. Int J Cancer. 2014;135:2857-67.

27. Maus MV, Thomas AK, Leonard DG, Allman D, Addya K, Schlienger K, et al. Ex vivo expansion of polyclonal and antigenspecific cytotoxic T lymphocytes by artificial APCs expressing ligands for the T-cell receptor, CD28 and 4-1BB. Nat Biotechnol. 2002;20:143-8.

28. Bagheri S, Yousefi M, Safaie Qamsari E, Riazi-Rad F, Abolhassani M, Younesi V, et al. Selection of single chain antibody fragments binding to the extracellular domain of 4-1BB receptor by phage display technology. Tumour Biol. 2017;39: 1010428317695924.

29. Kim YJ, Brutkiewicz RR, Broxmeyer HE. Role of 4-1BB (CD137) in the functional activation of cord blood CD28- CD8+ T cells. Blood. 2002;100:3253-60.

30. Margina D, llie M, Manda G, Neagoe I, Danciulescu-Miulescu R, Purdel CN, et al. In vitro effects of prolonged exposure to quercetin and epigallocatechin gallate of the peripheral blood mononuclear cell membrane. Cell Mol Biol Lett. 2014; 19:542-60.

31. Daniel-Meshulam I, Horovitz-Fried M, Cohen CJ. Enhanced antitumor activity mediated by human 4-1BB-engineered T cells. Int J Cancer. 2013;133:2903-13.

32. Jin HB, Lu L, Xie L, Yang JF, Zhang XF, Ma SL. Concentration changes in gemcitabine and its metabolites after hyperthermia in pancreatic cancer cells assessed using RP-HPLC. Cell Mol Biol Lett. 2019;24:30.

33. Qamsari ES, Sharifzadeh Z, Bagheri S, Riazi-Rad F, Younesi V, Abolhassani M, et al. Isolation and characterization of anti cmet single chain fragment variable (sCFv) antibodies. J Immunotoxicol. 2017;14:23-30. 
34. Wen T, Bukczynski J, Watts TH. 4-1BB ligand-mediated costimulation of human T cells induces CD4 and CD8 T cell expansion, cytokine production, and the development of cytolytic effector function. J Immunol. 2002;168:4897-906.

35. Ni X, Li XZ, Fan ZR, Wang A, Zhang HC, Zhang L, et al. Increased expression and functionality of the gap junction in peripheral blood lymphocytes is associated with hypertension-mediated inflammation in spontaneously hypertensive rats. Cell Mol Biol Lett. 2018;23:40.

36. Rosenberg SA. Cell transfer immunotherapy for metastatic solid cancer-what clinicians need to know. Nat Rev Clin Oncol. 2011;8:577-85.

37. June CH. Adoptive T cell therapy for cancer in the clinic. J Clin Invest. 2007;117:1466-76.

38. Jena B, Dotti G, Cooper $\sqcup$. Redirecting T-cell specificity by introducing a tumor-specific chimeric antigen receptor. Blood. 2010;116:1035-44.

39. Johnson LA, Morgan RA, Dudley ME, Cassard L, Yang JC, Hughes MS, et al. Gene therapy with human and mouse T-cell receptors mediates cancer regression and targets normal tissues expressing cognate antigen. Blood. 2009;114:535-46.

40. Cooper D, Bansal-Pakala P, Croft M. 4-1BB (CD137) controls the clonal expansion and survival of CD8 T cells in vivo but does not contribute to the development of cytotoxicity. Eur J Immunol. 2002;32:521-9.

41. Shuford WW, Klussman K, Tritchler DD, Loo DT, Chalupny J, Siadak AW, et al. 4-1BB costimulatory signals preferentially induce CD8+ T cell proliferation and lead to the amplification in vivo of cytotoxic T cell responses. J Exp Med. 1997;186: 47-55.

42. Dudley ME, Wunderlich JR, Robbins PF, Yang JC, Hwu P, Schwartzentruber DJ, et al. Cancer regression and autoimmunity in patients after clonal repopulation with antitumor lymphocytes. Science. 2002;298:850-4

43. Chan FK. Three is better than one: pre-ligand receptor assembly in the regulation of TNF receptor signaling. Cytokine. 2007:37:101-7.

44. Son JH, Lee UH, Lee JJ, Kwon B, Kwon BS, Park JW. Humanization of agonistic anti-human 4-1BB monoclonal antibody using a phage-displayed combinatorial library. J Immunol Methods. 2004;286:187-201.

45. Compte M, Harwood SL, Muñoz IG, Navarro R, Zonca M, Perez-Chacon G, et al. A tumor-targeted trimeric 4-1BBagonistic antibody induces potent anti-tumor immunity without systemic toxicity. Nat Commun. 2018;9:4809.

46. Lei G, Xu M, Xu Z, Gu L, Lu C, Bai Z, et al. A novel fully human agonistic single chain fragment variable antibody targeting death receptor 5 with potent antitumor activity in vitro and in vivo. Int J Mol Sci. 2017;18:2064.

47. Park KJ, Lee $\mathrm{SH}$, Kim TI, Lee HW, Lee CH, Kim EH, et al. A human scFv antibody against TRAIL receptor 2 induces autophagic cell death in both TRAIL-sensitive and TRAlL-resistant cancer cells. Cancer Res. 2007;67:7327-34.

48. Lu L, Wang X, Zhang A, Huang F, Yan Y, Li W, et al. Selection and expression of CD40 single chain variable fragment by phage display and evaluation of tumor specific immune activation. Int Immunopharmacol. 2019;71:224-32.

49. Gilbreth RN, Oganesyan VY, Amdouni H, Novarra S, Grinberg L, Barnes A, et al. Crystal structure of the human 4-1BB/41BBL complex. J Biol Chem. 2018:293:9880-91.

50. Bitra A, Doukov T, Croft M, Zajonc DM. Crystal structures of the human 4-1BB receptor bound to its ligand 4-1BBL reveal covalent receptor dimerization as a potential signaling amplifier. J Biol Chem. 2018;293:9958-69.

51. Li Y, Tan S, Zhang C, Chai Y, He M, Zhang CW, et al. Limited cross-linking of 4-1BB by 4-1BB ligand and the agonist monoclonal antibody Utomilumab. Cell Rep. 2018:25:909-20.

\section{Publisher's Note}

Springer Nature remains neutral with regard to jurisdictional claims in published maps and institutional affiliations.

\section{Ready to submit your research? Choose BMC and benefit from:}

- fast, convenient online submission

- thorough peer review by experienced researchers in your field

- rapid publication on acceptance

- support for research data, including large and complex data types

- gold Open Access which fosters wider collaboration and increased citations

- maximum visibility for your research: over $100 \mathrm{M}$ website views per year

At $B M C$, research is always in progress. 